\section{Policies may be ignored}

This study suggests that the classic tools that California planners use to protect farmland may be only partially effective in deterring land speculators from buying agricultural land near cities. Policies designed to sustain and insulate viable agricultural zones (including spheres of influence boundaries, greenbelts and Williamson Act contracts) can have unanticipated outcomes when different cities apply them differently.

When cities tend to change zoning designations and planning restrictions, land speculators expect that given enough pressure, these policies will be altered in subsequent plan revisions. As a result, the speculative land market drives up the price of agricultural land near cities. One significant result of this is that farmland, traded for its agricultural production potential, cannot compete because the land is worth less when used for agriculture than for development.

The effectiveness of planning tools used by local communities needs to be re-examined: planners should develop alternative farmland protection policies that account for market forces. What we really need is a broad spectrum of new tools used in conjunction with zoning. This could include purchase or dedication of easements as well as more consistent application of zoning. What is missing is an appreciation of the fact that markets and market perception influences investment decisions. When the land market senses inconsistency or reversal of policy, speculations occurs, which spurs pressure to change plans. Without clear, consistently applied landuse policies, farmland will tend to act simply as a bank for future development opportunities.

M.C. Moore is a Ph.D. candidate, Department of Land Economy, University of Cambridge, England; and commissioner for the California Energy Commission, Sacramento.

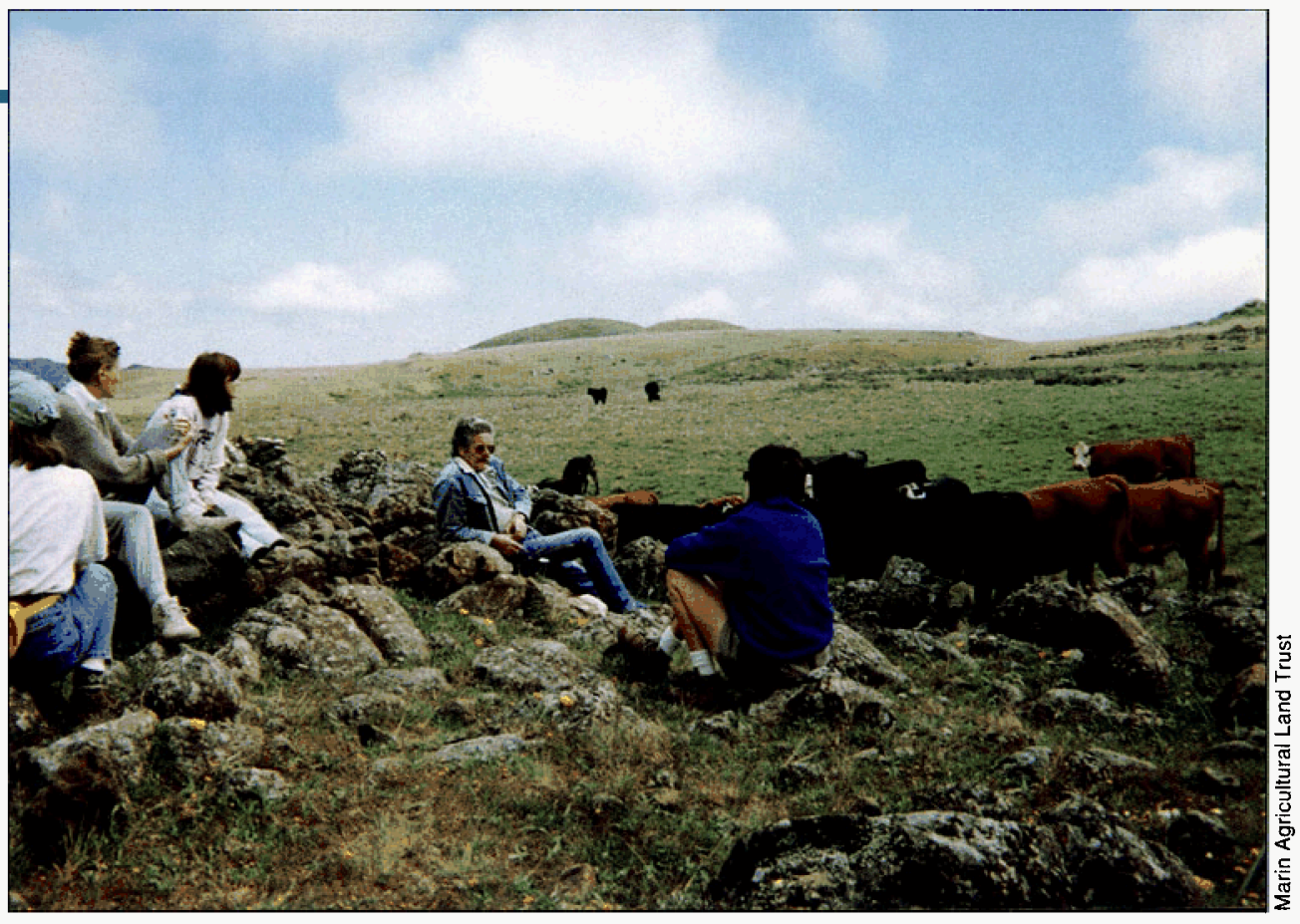

To promote public awareness of the importance of agriculture and the need to preserve it, the Marin Agricultural Land Trust gives tours of West Marin's farms and ranches. Rancher Richard Respini, center in blue jacket, talks to a tour group about the workings of his beef ranch, which is protected by a MALT agricultural conservation easement.

\title{
Land trusts conserve California farmland
}

Erik Vink

Communities can conserve farmland with land-use plans and zoning ordinances, but regulatory efforts are often transitory because future elected officials can revise them. To protect the land in the long term, agricultural land trusts work on a voluntary basis with individual landowners to acquire conservation easements that permanently restrict nonagricultural development of farmland. Farmers and ranchers are beginning to accept and support agricultural land trusts, which indicates that these trusts will continue to thrive.

A s the nation's top-producing agriAcultural state and also the fastestgrowing, California loses approximately 100,000 acres of agricultural land to urbanization annually. Because of the location of this growth, the state's best farmland is disproportionately affected, which has led to a strong public interest in protecting it.

Farmland conservation efforts have historically focused on land-use regulation by local governments. Local general plans and zoning ordinances have served to separate agricultural areas from incompatible land uses, such as urban uses where people congregate. While these regulatory efforts can be highly effective for a time, they are often transitory because the next group of elected officials can revise them.

The impermanence of regulatory efforts has led to a growing interest in efforts to protect farmland permanently. These efforts are carried out primarily by agricultural land trusts, which are private land conservation organizations. Agricultural land trusts work on a voluntary basis with individual landowners to acquire conser- 
vation easements that permanently restrict nonagricultural development of farmland.

Land conservation organizations have been protecting important natural resources in California since the early part of the century. Until the mid-1950s, these organizations focused largely on protecting coastal land in Northern California. Today California has more than 115 land trusts (Land Trust Alliance 1995) protecting a great diversity of land types including wetlands, forests, trails, archaeological sites, sea dunes, riparian corridors and wildlife habitat. There is also an important - and growing - group of land trusts that focus on protecting the state's rich agricultural land. These are largely a result of the growing recognition that agricultural land's food-producing capability makes it an important resource.

\section{Preserving farmland, open space}

California has 14 agricultural land trusts (table 1) that are distinguished from other land conservation organizations by two primary attributes: the focus is protecting farmland and the governing board includes a strong representation of farmers. The state also has about 10 other land trusts that are working to protect farmland as part of larger efforts to preserve open space. Examples of these organizations include the Peninsula Open Space Trust, Sonoma Land Trust, Riverside Land Conservancy and the Land Trust of San Luis Obispo County.

Agricultural land trusts help conserve farmland primarily by acquiring interests in land, advancing policy efforts to protect farmland, and promoting educational efforts to highlight the importance of farmland.

Acquiring interests in farmland. While other land conservation organi- zations prefer to protect land by purchasing it outright, agricultural land trusts typically protect farmland by buying conservation easements or "development rights," as they are known in the eastern United States. Conservation easements are deed restrictions granted by a property owner to restrict the type and amount of development that may take place on his or her property (Diehl and Barrett 1988). Agricultural land trusts are primarily interested in prohibiting future urban development and leaving the land in private ownership and management to be farmed by a farmer. Thus, conservation easements can protect farmland without incurring the ownership and management responsibilities associated with outright purchase.

Land trusts can acquire conservation easements from landowners through either donation or purchase. When donated, the conservation easement's value (the amount by which the easement decreases the land's fair market value), is considered a charitable contribution by the Internal Revenue Service and so can be tax deducted. As an example, vineyard owners have donated conservation easements on several thousand acres to the Napa County Land Trust and the Monterey County Agricultural and Historical Land Conservancy.

Agricultural land trusts that have the funding to purchase conservation easements are the most successful at protecting farmland, largely due to the inability of most cash-poor, land-rich farmers to donate conservation easements on their land. When conservation easements are purchased, the landowner receives a cash payment for the value of the deed restriction. The most successful example of this 


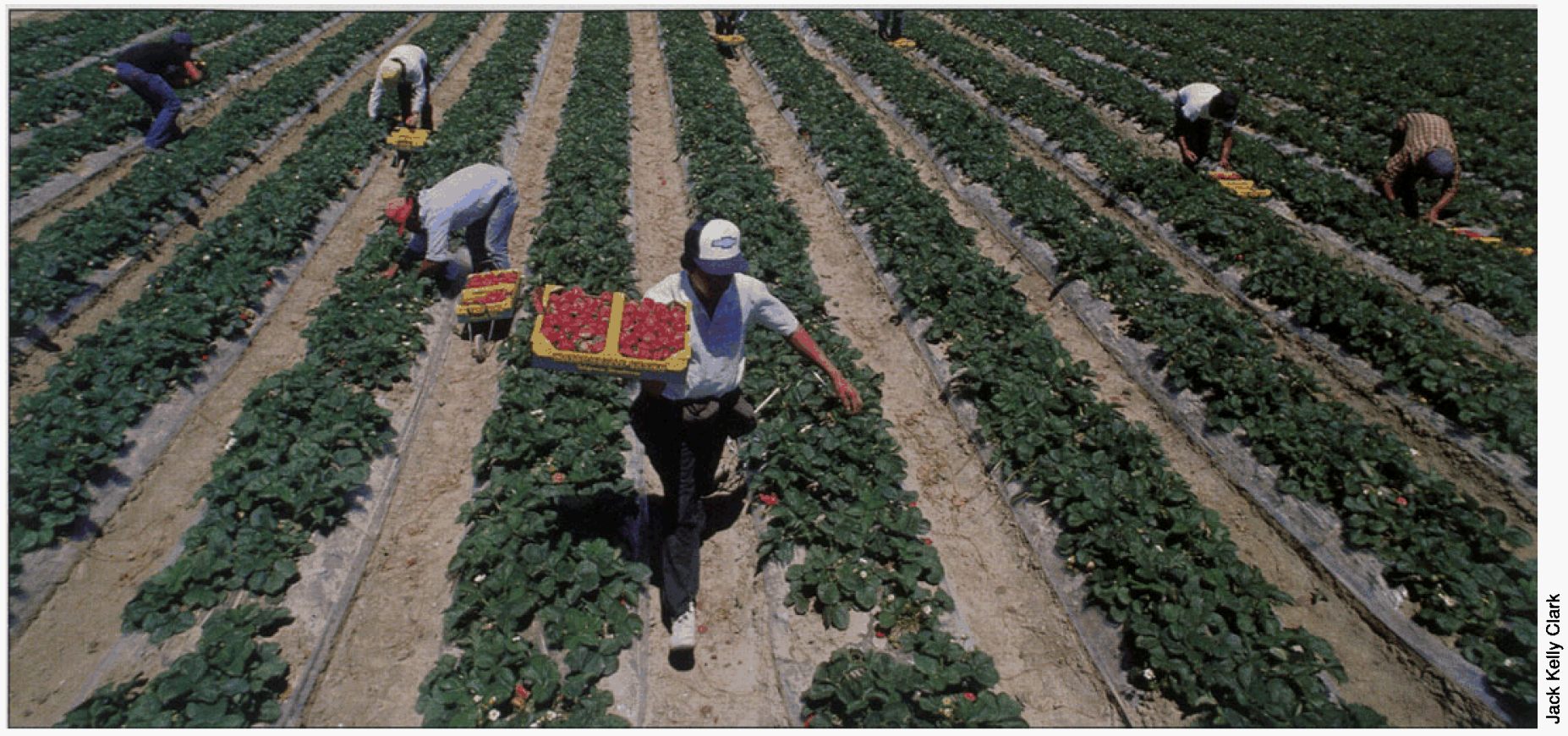

Conservation easements are increasingly being used to protect land where high-value crops, such as strawberries, are grown.

effort in California has been the Marin Agricultural Land Trust's purchase of conservation easements that protect more than 25,000 acres of West Marin grazing land (Faber 1997).

Agricultural land trusts can also be granted conservation easements as mitigation when local jurisdictions allow nonfarm uses on other agricultural parcels. For example, under the City of Davis's 1995 Farmland Preservation Ordinance, developers who convert agricultural land to urban use are required to mitigate the farmland loss by protecting an equal area of remaining farmland with a conservation easement. These easements are co-held by the City of Davis and the Yolo Land Trust, and the Trust is charged with monitoring the protected farmlands to ensure compliance with the easement.

Policy efforts to protect farmland. As nonpolitical organizations working on a private and voluntary basis with landowners, land trusts are often "policy neutral" and rarely become involved in land-use decision-making. Some of California's agricultural land trusts are quite active in local policy efforts. Often these trusts are attempting to advance farmland protection efforts while they work to establish programs for acquiring conservation easement.

Another reason some agricultural land trusts are involved in local land- use policies is that they were formed in response to controversial land-use issues. The Land Utilization Trust, for example, was formed in 1992 in San Joaquin County to settle a lawsuit brought against developers by a local environmental organization. The Land Utilization Trust has been very active in general plan discussions for San Joaquin County and the City of Stockton, and has advocated farmland mitigation for general plan updates that would convert large tracts of farmland to urban use.

Educational efforts to protect farmland. All land trusts are involved in educational efforts, usually to inform landowners about conservation easements. This work is largely accomplished by producing and distributing brochures and pamphlets, and occasionally by sponsoring seminars explaining the tax implications of conservation easement sale/donation.

Some agricultural land trusts are also involved in more general efforts to educate the communities they serve about agriculture or conservation issues. This tends to be especially true for newer organizations that have not yet developed successful programs for acquiring conservation easements. Like nearly all fledgling agricultural land trusts, the North Delta Conservancy does not yet have much funding for acquiring conservation easements.
However, the conservancy does have a very successful program that encourages landowners in the Delta region of Sacramento County to install wood duck boxes, which provide safe places for hens to incubate their eggs. This organization also focuses on educating schoolchildren about the agricultural, natural and historic resources of the Sacramento Delta region.

\section{Agricultural land trust history}

The first agricultural land trust in California - and in the nation - was the Marin Agricultural Land Trust, which was created in 1980 . Several defining factors have played key roles in the establishment and success of the state's agricultural land trusts.

California State Coastal Conservancy. The Legislature created the State Coastal Conservancy in 1976 to protect, restore and enhance coastal resources. Established in the wake of the voter-approved California Coastal Plan, which mandated more land-use controls over coastal lands, the Conservancy offers property owners incentives to voluntarily participate in its conservation programs. The Conservancy is authorized to acquire interests in coastal agricultural lands, as well as nonagricultural lands, to keep them from being converted to other uses (Coppock and Ames 1989). 


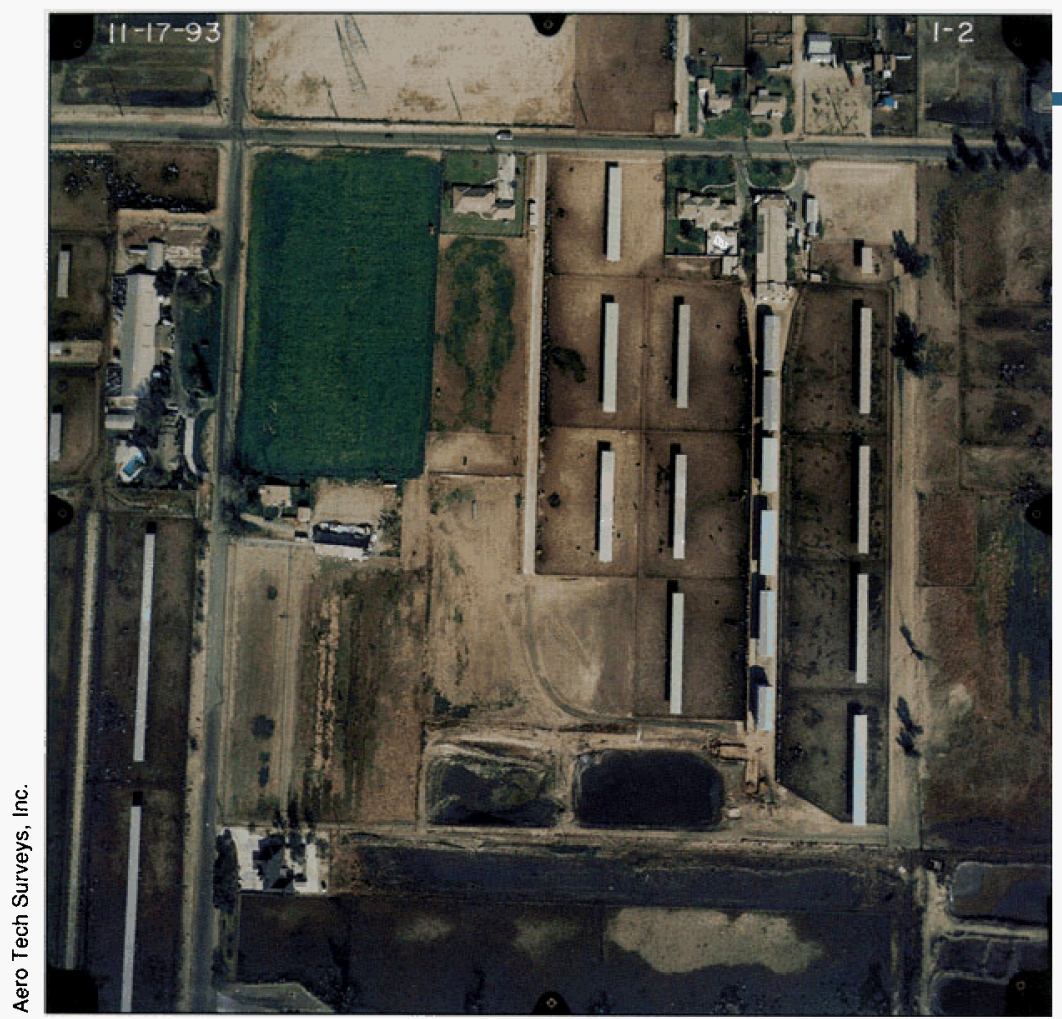

The Southern California Agricultural Land Foundation bought this 40-acre Chino Valley dairy to protect it from development in Southern California. The foundation leases the dairy and puts the profits toward property management and future land acquisitions.

In 1979 the State Coastal Conservancy adopted agricultural policy criteria that signaled its intent to provide funds to nonprofit land trusts to carry out conservation activities consistent with its mission. In 1984, the State Coastal Conservancy approved a $\$ 1$ million grant to the Marin Agricultural Land Trust for a demonstration project to protect West Marin ranchland. The conservancy also approved similar grants for projects in Monterey and Sonoma counties.

Subsequently, the State Coastal Conservancy also provided financial support for coastal farmland conservation efforts by other organizations including the Peninsula Open Space Trust, Land Trust of Santa Barbara County and Sonoma Land Trust. By supporting coastal farmland conservation, the conservancy inspired the creation of agricultural land trusts in places such as Monterey and Ventura counties.

Proposition 70 (California Wildlife, Coastal and Park Land Conservation Bond Act). Approved by Califor- nia voters in 1988, Proposition 70 included $\$ 63$ million for farmland protection activities in eight California counties (primarily for Marin, San Bernardino and Riverside counties, with lesser amounts for Monterey, Santa Barbara, Santa Cruz, San Mateo and Sonoma counties). Besides providing a tremendous boost to fledgling agricultural land trusts, Proposition 70 signaled that organized land conservation efforts in any part of California might benefit from funding in future state general obligation land-conservation bond measures. This was no small factor in the subsequent establishment of a number of agricultural land trusts throughout California, such as the Yolo Land Trust and the San Joaquin County Open Space and Farmland Trust.

Release of reports/calls to action. Several agricultural land trusts were created in response to reports calling for their establishment. For example, a 1989 American Farmland Trust report called "Risks, Challenges and Opportunities: Agriculture, Resources and Growth in a Changing Central Valley" was instrumental in the establishment of both the San Joaquin Open Space and Farmland Trust and the Merced County Farmland and Open Space Trust.

Local ballot measures. In 1990 , Sonoma County residents voted to establish the Sonoma County Agricultural Preservation and Open Space District, which is funded by a quarter percent increase in the local sales-tax rate over a 20 -year period. This public agency protects open space and agricultural land, focusing primarily on acquiring conservation easements on farmland. The district enjoys an annual funding stream of nearly $\$ 10$ million and has protected more than 25,000 acres of land, the majority of which is agricultural. Local farmland conservation efforts throughout the state have taken note of Sonoma's effort and several Central Valley counties are seriously discussing forming agricultural land trusts as a first step in replicating the Sonoma model.

\section{Future prospects}

The prospect for the continued health and growth of agricultural land trusts in California is quite favorable for two reasons: funding to acquire conservation easements on agricultural land is likely to increase, and farmland owner support for agricultural land trusts is growing.

The Agricultural Land Stewardship Program. Created by state legislation in 1995 and administered by the California Department of Conservation, the Agricultural Land Stewardship Program provides grants for land trusts and local governments throughout the state to acquire conservation easements on agricultural land. Although initially funded for only $\$ 1$ million in fiscal year 1996/97, the amount grew to $\$ 3.7$ million in the governor's fiscal year 1998/99 budget. While this funding level is modest, the success of initial acquisitions and growing interest on the part of landowners will likely generate additional support to greatly expand the amount of funding available for farmland conservation efforts in California. The Agricultural Land Stewardship Program has already matched federal funding available from the 1996 Farm Bill's Farmland Protection Program. California has received nearly $\$ 2$ million, which has been used to purchase conservation easements on farmland.

Acceptance of agricultural land trusts by farmers/ranchers. The most favorable sign that agricultural land trusts will continue to thrive and pros- 
per is that agricultural landowners are beginning to accept and support them. An increasing number of farmers and ranchers serve on the boards of directors of agricultural land trusts. In addition, farmers and ranchers have become increasingly involved in recent discussions about the vital role that these trusts and conservation easements play in providing options for farmland conservation. These discussions have been held by groups such as the California Cattleman's Association and the Agricultural Task Force for the Central Valley, a private task force of prominent agriculturists seeking consensus of farmland conservation efforts.

Thanks to the ambassadorship of farmers and ranchers serving on agricultural land trusts' boards of directors, as well as the positive stories of landowners who have worked with them, agricultural land trusts and their conservation easement activities are meeting increasing favor from the larger agricultural community. The goodwill and favorable impression that landowners are left with after working with agricultural land trusts is highlighted by the fact that farmers and ranchers now perceive these organizations to be "accepted tools for farmland conservation" rather than "private property rights abridgement."

A great contributor to this increased support is the policy evolution of major agricultural organizations. The California Farm Bureau Federation, for example, has supported conservation easements and the role of agricultural land trusts for several years and was a strong supporter of the Agricultural Land Stewardship Program legisla-

tion. But this evolution is perhaps best illustrated by the Colorado Cattlemans' Association, which formed a land trust in 1995 to protect ranch properties throughout that state.

\section{Conservation efforts expand}

California's efforts to conserve agricultural land are expanding to new areas of the state and increasing their conservation easement activity. But these efforts will continue to be constrained by two factors: the level of interest in participating and the lack of available funding. Conservation easement programs will appeal only to a certain group of landowners, largely because many landowners are hesitant to place a permanent restriction on what is, for many, their primary asset. However, the limitation of funding is a far greater constraint. In a state with as much threatened agricultural land as California, it will take more than several million dollars a year to provide for more than a few farmland protection demonstration projects.

Even so, the potential for advancing farmland conservation efforts is great. Far from being solely involved in direct land protection, agricultural land trusts are also involved in efforts to educate public officials, landowners and the general public about the value of agriculture and the use of agricultural conservation easements as a tool to protect farmland in a community. In addition, agricultural land trusts are expanding their involvement into local policy efforts to protect farmland. All of these efforts supplement and support agricultural land trusts' primary function of permanently protecting important agricultural lands from urbanization.

E. Vink is California Field Director for American Farmland Trust, a national nonprofit farmland conservation organization. He is based in Davis.

\section{References}

American Farmland Trust. 1989. Risks, Challenges and Opportunities: Agriculture, Resources and Growth in a Changing Central Valley. San Francisco, California.

Coppock D, Ames L. 1989. Evaluation of Agricultural Land Trusts. California State Coastal Conservancy. Oakland, California. Diehl J, Barrett TS. 1988. The Conservation Easement Handbook. Land Trust Exchange/ Trust for Public Land. Alexandria, Virginia. Faber P. 1997. The Marin Agricultural Land Trust: A Case Study.

Land Trust Alliance. 1995. 1995 National Directory of Conservation Land Trusts. Washington, D.C. 